\title{
Mediations of 'the Refugee Crisis': The (Ir)reconciliation of Ideological Contradictions in Fortress Europe
}

\author{
ALEXANDER CALLUM HARRISON, Queen Mary University of London
}

\begin{abstract}
In the UK, the summer of 2015 saw the national popular press and public imagination captivated by the 'refugee crisis'. On both mass and social media sites, public opinion predominantly orientated around two major narratives. On one hand, amidst the dramatic scenes in Calais (as well as elsewhere), the European media worked into a fervour of fear, amid concerns about the 'swarms' of migrants purported to be 'invading' Europe (Squires 2015, The Telegraph). Taking a theoretical focus through Agamben's work and giving reverence to where his concerns converge with aspects of postcolonial theory, the following investigation unpacks how the hegemonic (new) media narratives have intensely cycled into an emotionally charged dichotomous discourse obfuscating a multitude of other key considerations. Employing content analysis, this article reads three cultural texts scraped from social media to discuss the ways in which the construction of the refugee identity has been shaped in the public imagination; it calls into question how forefronting the figure of the refugee has foreclosed wider debates about alternative agendas contributing to the processes of Fortressing Europe.
\end{abstract}

\section{KEYWORDS}

Social media, mediation, refugee crisis, bordering, biopolitics

\section{Introduction}

The steep increase in migrants and refugees seeking asylum in Europe, during and since the summer of 2015 , is now referred to by media as 'the refugee crisis'. This crisis has invoked responses from national leaders across Europe: David Cameron described the UK need to 'protect [...] borders' (Taylor Wintour and Elgot 2015, in The Guardian Online). Symptomatic of this surge in concerns about state security, across Europe there has been a renewal in nationalist sentimentality and articulations calling for greater control of European borders. Propelling this, the online media presence of right and far right organisations has also grown. Members of organisations like Britain First, The British National Party, Pegida (UK) and many others have effectively initiated campaigns across social media. Simultaneously, symbolic of another major narrative prevalent in describing this crisis, news and social media disseminated Nilufer Demir's photograph of Aylan Kurdi's body being pulled from the Mediterranean Sea. This potent image was a powerful re-presentation of the tragic life and death realities within the refugee crisis in and around the Mediterranean; exemplary of Europe's waning humanitarian efforts, the image was quick to spread around the world in mass media, and along social networks. 
The scenes of this story are familiar: images of dead children on beaches, refugee camps and multiple counts of individuals pulled off boats or blocked by fences, together paint a powerful picture. These images have become lexicons and intrinsic motifs reflective of the changes and transitions in geo-politics. They are the tragic spectacle emblematising the fault line between Fortress Europe and Other continents (Said 1978). This multitude of images pertain to the contradictory characteristics labelling as swathe/'swarm' individuals seeking refuge/'plotting to enter Europe' (Blanchard 2015 The Mirror). These images symbolise the contradictions coloring Europe: the liberal-humanitarian element of European ideology has come into stark and obvious conflict with the individualist, nationalist and racist elements. Drawing upon the work of Giorgio Agamben (1998-2009), these images signify the growing tensions between the principles of universal human rights and state sovereignty, as well as the compounding problematic of statelessness, and the reduction of human rights to biopolitical humanitarianism (Fassin and D'Halluin 2005).

Tapping into such concerns, this paper unpacks three texts scraped from social media (Barthes 1975). Content analysis will be employed to contextualise these cultural artifacts; they will be used as portals to measure the socio-political contexts within which they were forged. These texts will be considered as both products of and contributors to the narratives pertaining to refugee identity construction. Whilst the images relate to online concerns over the refugee 'influx' into the UK, they are reflective of broader xenophobic tendencies echoed across Europe. Indulging aspects of the work of post-structuralist political philosopher Giorgio Agamben, and drawing upon veins running through postcolonial theory (Said 1978; Spivak 1988), this article considers these texts in relation to how the discourse surrounding the refugee crisis has been constructed online, and within the public imagination (Seiter 1989; Orgad 2012). This paper considers processes of refugee identity construction; viewing the crisis through these online media artifacts, it contemplates refractions as symptomatic of the contemporary new(s) media ecology. This article advocates that the politically charged nature of the current refugee crisis stimulates a variety of fragmented reactions/realities; however, ensnared within the key contradictions undergirding Europe's engagement with the refugee crisis, the hegemonic narratives too heavily focus around two core limited and limiting themes. The dogmatic narratives holding hegemony have subsequently become locked in dangerous self-fulfilling cycles; in so doing, in a process that a) regurgitates narratives prevalent in (post)colonial discourse and that b) can be likened to the construction of Giorgio Agamben's figure of homo sacer, both the media and the physical barriers across Fortress Europe have constructed refugees as a fearful Other, and simultaneous victim - a biopolitical paradigm of the modern - relegated to inhabit the camp. Whilst indulging Agamben's contentions, this paper also critically reflects upon some of the teleological problems inherent with the adoption of these theoretical and conceptual paradigms. Crucially, Agambian logic locks and limits the debate into a conceptual cycle considering issues relating to sovereign power, legal discourses of control, spatial-cognitive boundaries and the politics of rights. In an attempt to break free from this cycle, the following paper is a call to consider one of a multitude of other significant contributing factors that could complement and enrich the refugee debate. In this vein, I open by giving reverence to the complex networks and nexus formed from the self-fulfilling cycles and self-reinforcing economies formed through the fortification of Europe. 


\section{Fortressing Europe: Border Security Policies and a Growing Industry}

Over 2014, six hundred thousand people arrived in Europe in search of asylum (Journalism ++ 2015). Before the erection of some of the more draconian defence mechanisms employed to fortify Europe and restrict entry, such as the sharp-bladed concertina wire used in Hungary, refugees and asylum seekers battled with numerous other physical, financial, bureaucratic and electronic barriers. Along European borders, financing has poured into European security efforts to halt migration. This spans Europe and stretches as far as Niger's crossroad town of Agadez, at the edge of the Sahara (Andersson 2015). Military-grade technologies supplied by private companies, spawned through research and development programs financially backed by EU subsidies (Journalism ++), have been incremental in the fortification of Europe's borders. The emerging Euro-African border is one example of a larger case of fencing out unwanted Others, initiated across the globe. Anti-immigrant barriers in Spanish enclaves bare a stark resemblance to Israel's desert borders, as well as those along the Greek-Turkish frontier. Shared logics see Western states adopting similar 'innovations', and as is often the case within the fortification of Fortress Europe, nation-states contract the same companies and consulting firms to do this job (Andersson 2014). With Eurosur having secured a budget of $€ 244$ million, border security is growing to be a huge industry; the vast set of straggling defences, edified at extraordinary cost, signify the physically enacted response to the sense that Fortress Europe is under siege.

The dogmatic narratives currently characterising the (new/s) media cycles do little to call into consideration these facts and figures. But rather, as shall be explored below, the figure of the Other - both (im)migrant and refugee - has been positioned as a perennial outsider, yet in the foreground of debates captivating the Western imagination; the (im)migrant/refugee has become the bogeymen invading Europe in waves and floods (Taylor Winter and Elgot 2015). Taking a prominent position at the forefront of the political imaginary, the refugee constitutes a threat lurking at the gates of Fortress Europe. With a haunting resemblance to colonial discourses (Said 1978), the refugee signifies the global pariah:

'[A]n object of deep fascination and utter indifference, or horror and pity, he stalks the borders of the rich world, sowing panic, wrecking election campaigns, and generating headlines as he goes'. (Andersson 2014, 3)

As attested by Andersson, the way in which the (im)migrant, refugee and asylum seeker identity has been constructed has significant implications. Evidenced in the cultural artefacts analysed in this investigation, the public gaze and imagination is so caught up with the figure of the (im)migrant/refugee that disproportionately significant amounts of attention have been detracted from the complex arrays of networks and industries growing through and from the fortressing of Europe.

Overshadowed by the hyper emotively charged binary of anti-immigration vs. humanitarian narratives, fortifying Europe's borders marks the latest permutation of the long-established nexus of European state policy and the interests of capital. Shifts in geo-politics, and the current crisis, continue to be financially fortuitous for the immigration detention and military industrial complexes. Considering the popularity of this polemic subject, the price of fortifying Europe receives little media attention. 
The following section thus turns attention to considering what narratives do hold hegemony within the (new) media rhetoric. This process, focusing in upon the ideologically charged lenses eschewing engagements with the refugee crisis, enables a better understanding of why the competing dogmatic narratives have fervored and facilitated a process of fortifying Europe; in so doing this article brings to light the ways in which the current streamlined dichotomy has obfuscated significant Other voices and important issues also due for consideration.

\section{$\operatorname{New}(\mathbf{s})$ Media(tions)}

'[...] the decisive part of the interaction between social movements and political authorities is no longer the direct, physical confrontation between them in concrete locations, but the indirect, mediated encounters among contenders in the arena of the mass media public sphere' (Koopmans 2004, 367).

Embroiled into complex media assemblages constituting the contemporary media ecology, social and mass media have become critical players in mediating public opinions and engagements with crisis situations, and governmental responses. Medias remain discursively active; they shape popular understandings of citizenship (its insides and outsides), the discursive and structural (re)production of social, cultural and political marginality via constructions of voiced and silenced, orderly and disorderly, normative and non-normative, citizens, non-citizens, figures of fear and figures of pity. Within the current debates on the refugee crisis, many voices and arguments are marginalised. In the UK's media the voices of refugees, (im)migrants and asylum seekers remain as a suppressed silent subaltern Other (Spivak 1988). Whilst the images of refugees have formed a focal point for many mass media outlets, with the exception of some more progressive journalism (ViceNews 2015a; GuardianOnline 2015), few efforts have employed a dialogue that might engender emancipating a more nuanced engagement with this crisis.

'Mediation is disclosed in media events that open up "existential moments" of awareness, of our awareness of being in the world. Media events are thus able to disclose "being-as-mediated" by virtue of anomaly, of 'standing out in time' (Kember and Zylinska 2012 40).

The issue of cross-border movements has been displaced onto a first world/third world divide, designed to keep the 'Rest', or Other, away from the 'West,' yet still premised upon liberal exclusions and understandings of difference (Said, 1978); dialogues remain ensnared in-between irreconcilable ideological contradictions that re-capitulate contentions echoing Agamben. Nation state interventions into the movement of the 'transnational subaltern subject' are articulated and justified primarily from the perspective of the self-protectionist European states (Spivak 1985; Otto 1996). In this process of streamlining debates in the current of the online media ecology, within which dialogues have become refracted and displaced onto a discursive dichotomy and locked into a back and forth binary, concerns appear limited to anti-immigrant/refugee populism vs. humanitarian narratives. 


\section{Narrative 1: The Fearful Other}

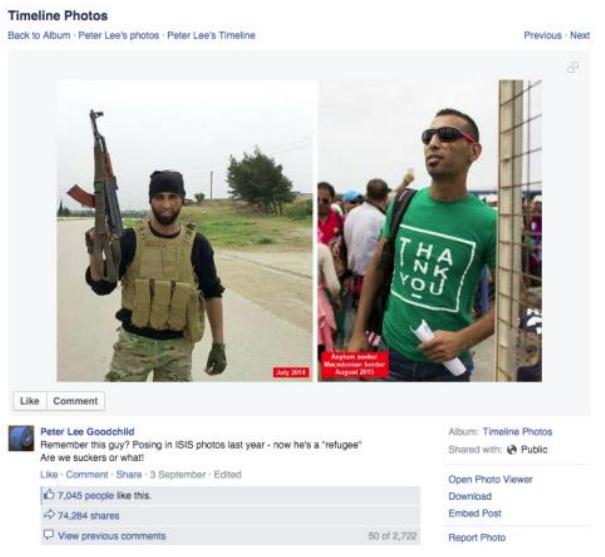

Figure 1

The British far and middle right has been among the most prominent factions of British society that demonstrated abject resentment to (im)migrants, refugees and asylum seekers entering the UK. By utilising social media platforms like Facebook, there have been widespread (mis)appropriations of imagery portending to demonstrate ISIS members claiming to be refugees entering into Europe. Doctored imagery has been posted (and subsequently debunked (ViceNews 2015b)) in attempts to evoke the idea that the refugee crisis is enabling an influx of ISIS insurgents to enter Europe. The above image is representative of a canon of public advocacy marketing aimed at fervoring a fear of refugees. The image presages to show an individual first as an ISIS fighter, and then posing as a refugee (Britain First 2015). This image, shared over 74 thousand times, actually depicts a former commander from the Free Syrian army (Hopkins 2015). The distribution of this image is a strong example, and one among many others, that shows right-wing media presenting misinformation in an attempt to influence audiences in favour of a particular ideological agenda. It is reflective of a strong narrative underpinning the British (far-)right's contentions regarding the entrance of refugees into Britain: the refugee crisis poses a national threat by enabling an influx of ISIS extremists to enter Britain. Similar opinions have also been reiterated in the Daily Mail (2015); '[t]he revelation comes as Lebanon warned two in every 100 Syrian migrants smuggled into Europe are ISIS-trained fanatics, with most travelling overland through Turkey to Greece.' Nick Fagge, writing for the Syria Border for MAILONLINE goes on to claim:

'[...]bogus papers are also being used by economic migrants from other Middle Eastern states who know that a Syrian asylum claim will be met with more sympathy following the civil war which has so far forced an estimated four million people to flee. The recent death of Aylan Kurdi, the three-year-old boy pictured after he was washed up on a Turkish shore, has heightened demands for countries to take in Syrian refugees and propelled their plight to the top of the international agenda' (Fagge 2015).

Such sentiments fall in line with a new kind of global imaginary that has taken hold of the Western public imagination, especially since the 9/11 attacks upon US landmarks; characterised by a fear of the Other, or what Michael Fisher (2006) terms 'fearism,' it 
signifies 'a process and discourse hegemony [which] creates an experience of fear that is normalized... keeping the cultural matrix of 'fear' operative' (Fisher 2006, 51). Since 9/11, media has played a prominent role in promoting a culture of fear and hostility towards immigrants, refugees and asylum seekers (Altheide 2002; Ahmed 2004; Furedi 2006). As epitomised by the crass scaremongering evident in right-wing social media pages, and their use of doctored imagery (see above) employed to evoke narratives implicating refugees into a plot in which they pose a danger to our very existence, fear of the Other is produced, circulated and capitalized on to achieve political and economic purposes (Robin 2004). The manner in which the British farright commandeer social media spaces utilises individual fears and directs them towards Others; fear then becomes a dominant relational mode that aligns bodies to a particular sense of belonging (Ahmed 2004; Zembylas 2010).

The ISIS threat is a particularly powerful cause for concern among Europeans at present. Consequently, as evidenced in the cultural media artifact above, a key thread running through many of the British far-right social media campaigns pushes forward the notion that refugees are linked to this threat: 'Fear produces fearful subjects in relation to fearsome others and secures the very boundaries between $u s$ and them' (Zembylas 2010, 33). In so doing, the politics of fear becomes a powerful motivational tool, thus legitimising restrictions upon space and movement. The draconian measures employed, such as Hungary's recent erection of a barbed wire fence restricting access from Serbia, stand as a strong symbolic gesture reflective of European reactions to the current crisis (Weaver and Siddique 2015, in Guardian Online). Nation-state efforts to restrict 'illegal' immigrants, 'un-qualified' refugees or 'bogus' asylum seekers take support from the flow of fear amongst 'legal' citizens; the erection of physical boundaries find legitimising support through a fear of how these Others may threaten the well-being of a state, or the character of a nation (Zembylas 2010). In the UK, and across an ever increasingly fortified Europe, 'governments continue to delegitimise refugees in the public eye today, cynically labelling them 'illegal' or 'economic migrants' (Elgot and Taylor 2015, in Guardian Online). The sentiments echoed around online news and social media pertain to significant consequences. The anti-immigration populism bounced around social and mass media propagates and consolidates fearism; in so doing, it plays a critical role in legitimising the bordering of Fortress Europe, and the UK. More potent still, the resulting situation arises in which, as Agamben puts it:

'What has been banned is delivered over to its own separateness and, at the same time, consigned to the mercy of the one who abandons it - at once excluded and included, removed and at the same time captured' (Agamben 1998, 10).

The current relationship between many refugees, asylum seekers and European states is characterised by sovereign abandonment. Individuals are removed from the legal system and excluded from the polity; their position is extremely vulnerable. Whilst this situation does not signify being cast back into being in the condition of zoe, as being human is marked by the impossibility of pure zoe (despite human rights theory contending the contrary), the state abandonment evident in the camps growing around different European borders signals the physical emancipation of Agamben's contentions. This is why it is imperative to engage with how (online) media(tions) broker this relationship, between the citizens of Western states, their governments and 
the subaltern Others relegated to inhabit the camps consigned to growing along European borders (Said 1978; Spivak 1988; Agamben 1998).

\section{Narrative 2: An-Other Victim}

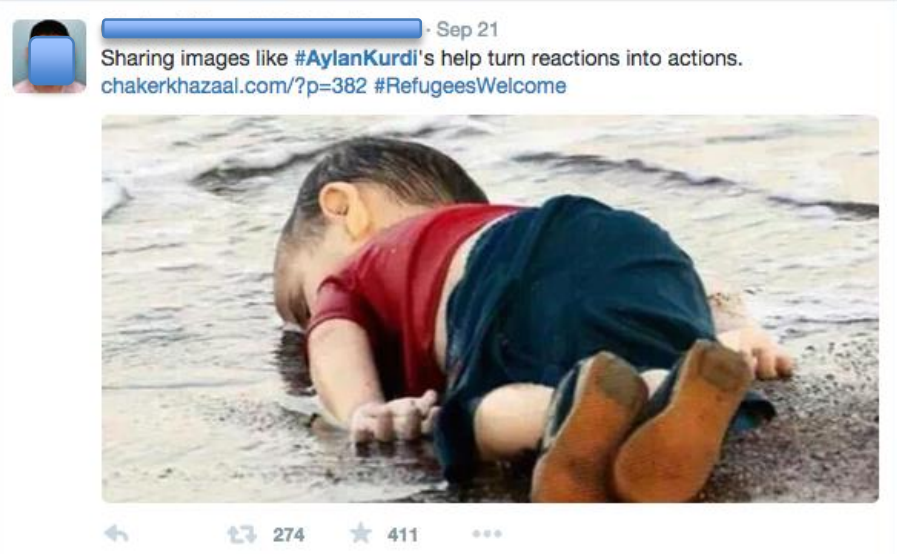

Figure 2

One of the central strategies employed in response to political discourses propagating the politics of fear-ism is to generate forms of recognition for refugees that work against identities constructing them as hate figures, or fearful Others (Tyler 2006). There is a diverse array of strategies employed to work against fearism; one of the most commonly employed strategies constructs refugee identities as victims. Evident in the social media artifact picturing the body of Aylan Kurdi, this strategy is particularly prevalent across online media; in a canon comparable to Spivak's work (1988), normative values relating to respect and sympathy ask 'humanitarian' subjects to sympathise with a human individual Other. 'Granting voices,' sharing intimate and personal narratives, this strategy counters the dehumanizing constructions witnessed in a number of mid-market newspapers, as well as (far and moderately) right leaning social media posts (Ibrahim 2011).

The information intertwined in the above image feeds into the debates dominating the European politic; this image pertains to the meat-hook life and death realities that form the underbelly of the anti-immigrant populism (re)produced by the discourse of fear-ism. Social and online medias are utilised by all sides within ideologically charged battles; different sides employ social media in order to construct (im)migrant/refugee identity for political and economic gains. The publication of the image of three-year old Aylan Kurdi is a strong example of how imagery can be used to effectively make a point about the refugee crisis. Using the image was criticised on the grounds that some saw the media's choice to publish the image to be capitalising on Kurdi's death, in order to highlight European indifference to Syrian suffering (Fahey 2015 The Guardian Online).

In ideological warfare, the figure of the child is a powerful symbol, and recurrent throughout political discourses spanning history; it has been, and remains, particularly prevalent within (post)colonial discourse (Said, 1978). The publication of such imagery is pure 'ideological combat;' the "photographs of the victims of war are themselves species of rhetoric. They reiterate. They simplify. They agitate. They create the illusion of consensus" (Sontag 1977, 6). Such images become a point 
around which negative identity can be formed. These images are meant to illicit a common feeling of shared humanity; all that view them are united by a common goal, to stop such atrocities occurring. This tactic of creating a binary seeks to align audiences with humanitarianism, advocating for an intervention to end 'the horror' (Young 1995). The dissemination of this image elicited David Cameron to comment how he was 'deeply moved' by the image; further to this he insisted that the UK would 'fulfill our moral responsibilities' (Dathan 2015, Independent.co.uk). Such examples pertain to how political figures in Western states are, in some way, often implored to acknowledge and respond to growing public discontent upon issues that feature heavily within the media. These responses pertain to the power imbued within (social) media's circulation of such polemic imagery.

This technique, using images of children in ideological combat, is comparable to the 'Afghan Girl' who appeared on the cover of the National Geographic in 1985 (Schwartz-DuPre 2012). Like Aylan Kurdi, the Afghan Girl provides a single and lonesome victim as a figure with which the viewer might better be able to conceptualise empathy and sympathy. Like the Afghan girl, Aylan Kurdi stands for a great many other people in need; his victim status constitutes a "simultaneous sense of both difference and identification. The image [of the Afghan girl] provokes sympathy that provides [American] audiences the ability to confirm their own identity while attudinally supporting her rescue" (Schwartz-DuPre 2012, 352). Establishing a victim, a child in need, enables the audience to configure their role, the White knight, "the saviour' (Mamdani 2010).

This is not to say that attempts to invoke sympathy should be deplored. On the contrary, the dissemination of such imagery provides a powerful portal into understanding the tragic elements of fortressing Europe. Nonetheless, in the schema of the ideological battles being waged across the UK and European media-scapes, these cultural artefacts are weapons, deployed in the ideological battles attempting to influence the European popular imagination (Shohat and Stam 1994).

Drawing upon veins present in postcolonial theory, as well as the work of Agamben, enables the contextualisation of the chosen cultural artefacts. These artefacts are reflective of the narratives holding hegemony; they signify the popular discursive contradictions haunting Fortress Europe. Considering the competing narratives, together mapping, marking, making and shaping the way the refugee crisis is considered within the UK (and European) public imagination, the images above act as lexicons and motifs for the contradictions underpinning contemporary debates in the dominant Western ideology/ies. These media artefacts point to how media(s) effect power relations; media can empower and disempower governments, citizens, refugees and asylum seekers. Media artefacts act as vehicles or obstacles to civic agency, social change, the erection and destruction of walls and borders, life and death. The power relations at play here jostle to relay competing ideological narratives: any process of mediation, particularly ones tapping into the politically charged and polarised narratives surrounding the current crisis, effect the play of power relations. The way these battles have been staged on social media has de-fracted and refracted articulations competing to strike resonance and affect the (meta)narratives surrounding the refugee crisis. In so doing, there has been a ricochet effect in how this crisis has been constructed. Narratives 1 and 2, described above, have dragged the debate into the realms of the absurd. The irreconcilability of these two discourses has 
resulted in the trivialisation of debates. As demonstrated below, social media has a propensity to trivialise issues; in so doing, some contentious aspects undergirding the refugee crisis are not given due reverence. A key issue with the current narratives, circling around national security vs. humanitarian concerns, is that they have marginalised and silenced Other voices and alternative considerations. Further to this, due to the irreconcilability of these ideological differences, debates deteriorate. The severity of the current crisis is so relentlessly unanswerable that those engaging with social media dialogues seem to propel down a back and forth diatribe tussling over these irreconcilable ideological contradictions; the violent real cannot be confronted directly (Zizek 2008).

\section{A Collision of Narratives: (Ir)Reconcilable Ideological Differences, An Anamorphosis Paradox and The Absurdity of the Real}

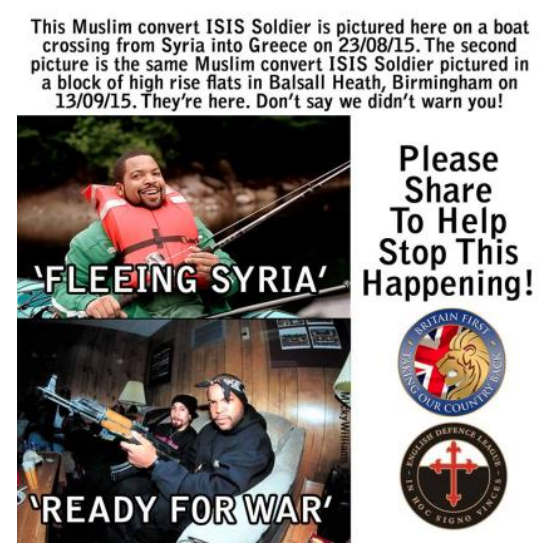

Figure 3

Born from these two competing narratives, spawned through the social nature of online media, online spaces have grown to play host to farce, satire and the absurd. As demonstrated by the cultural artifact above, there has been a propensity for users of social media sites to indulge in a process of mockery and point scoring. Sites such as Britain Furst have attracted over 142,000 likes; the site parodies the British far-right social media site, Britain First. The above image was created and posted by an individual user's personal Facebook profile page; the image was shared several thousand times, including upon Britain Furst's Facebook page, before then appearing upon online media sites such as The Independent Online and Vice News. The image plays upon the way far right political groups use doctored imagery in their social media posts, as described in narrative 1; it depicts US rapper (Ice Cube - although his identity is not given), 'fleeing Syria' and then in the UK, 'ready for war.' Since its publication the image received significant amounts of attention. The author of this meme claimed that the image was widely shared and re-posted, with ' 1 out of 10 shares being from a far-right supporter' who had failed to understand the intentions (Hopkins 2015). This image is representative of a larger trend occurring on social media; as illustrated by the Facebook page Britain Furst, which also featured this image, there have been numerous cases of doctored imagery and misinformation. Farce and fact are confused and repeatedly (mis)communicated or misunderstood across social media (Hopkins 2015). 
In a similar vein, the image of Albanians fleeing to Italy, featured below, has been banded around social media on numerous occasions, accompanied by different accounts as to what is being portrayed. The far-right group Pegida UK posted this image on their Facebook page, accompanied by comments demanding it to be 'torpedoed'. In a further twist, in a reverse Google image search the image occurred again, used by another Facebook user; he claimed that the image did not show Syrians but rather, it in fact showed 'Europeans boarding a ship to Africa during the World War.'

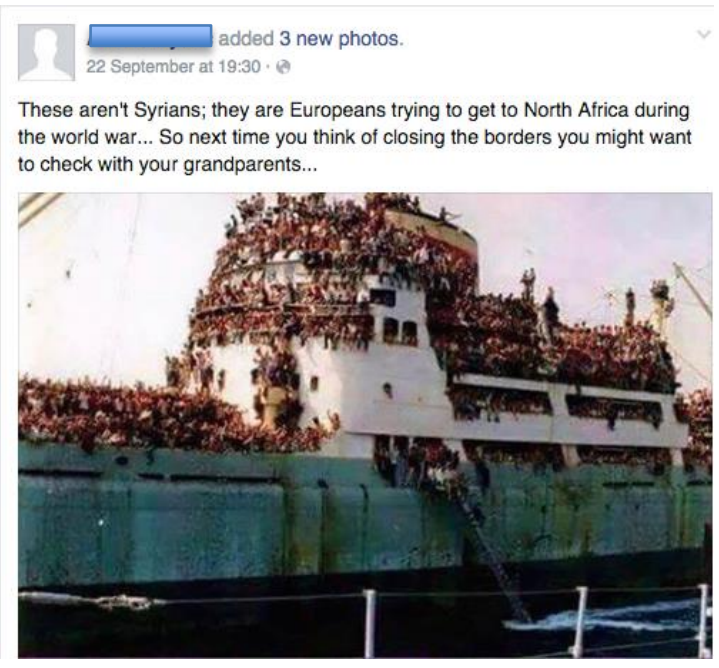

Figure 4

Caught up between the refractions of anti-immigrant populism, myths, humanitarian rhetoric, mockery, mistakes and farce, online spaces create a bizarre image of the current refugee crisis. The internet is awash with mockery and misinformation. The types of engagements online media structure is reflective of the misunderstood liminal spaces inhabited by asylum seekers, refugees and (im)migrants. They occupy a position within ideological considerations, yet they also remain excluded. The refugee issue is recognised as a crisis in need of attention, but bound in amongst the ideological contradictions of the European politik, the trajectory for engaging with this crisis remains unclear.

For Agamben (1998), the failure to rethink the separation of humanitarian and political concerns signifies a 'secret solidarity' between humanitarianism and the powers it should fight. The treatment of immigrants/refugees/asylum seekers as bare life demonstrates a failure to adequately engage with humanitarianism. The denouncement and conflation of both anti-immigrant and anti-refugee populism requires a great deal less; curtailed by limited and limiting options, the online dialogues have become stifled. Caught amongst these ideological contradictions, interlocking contradictory narratives have grounded positive potential moves forward. A severe problem of this is that important considerations become effaced. As outlined above in the section about Fortress Europe, the military industrial and immigration detention industries are flourishing. However, in the potent discursive dogmatics regarding the refugee crisis, the intensifying nexus between European states, immigration detention and military industrial industries are not sufficiently foregrounded. Feeding these hegemonic narrative flows detracts from other considerations, the significant financial flows being just one of many. As evidenced in 
the cultural artifacts considered, there are significant problems with the way in which social and online media have taken to overly indulging this discursive dichotomy.

\section{Agamben and the Discursive Dichotomy Forged Through Online Media Narratives}

Media assemblages and public imaginations play critical roles in constructing a discourse purporting the notion that refugees constitute an Other threat to state wellbeing and security. Undergirded by the notion that the Other constitutes a threat enables, facilitates and legitimises a desire and demand for the exclusion of the Other; this exclusion extends beyond just society and entry into European nation-states, but entails the exclusion from the sphere of human values, civic rights and moral obligations (Said 1978; Papastergiadis 2006; Tyler 2006). As can be seen in the multitude of camps emerging along different borders in Europe, on account of this extensive exclusion, and in line with Agamben:

'It would be more honest and, above all, more useful to carefully investigate... [the] deployments of power by which human beings could be so completely deprived of their rights...that no act committed against them could appear any longer a crime' (Agamben 1998, 171).

Giorgio Agamben's statement does come in need of some contextualisation; at first glance this post-structuralist approach appears to be in danger of conflating human and citizenship rights. But unpacking this differentiation contributes towards highlighting a contradiction inherent within liberal democracies: restricting the rights of certain groups whilst simultaneously holding these same rights as core values for citizens. It is important to note, despite human rights being born out of citizenship rights, these notions do not stand equal to one another. Citizenship rights refer to the relationship implied through the rights and obligations of states and citizens, as derived from membership of a particular political community. Human rights, on the other hand, infer the inalienable and universally applicable rights to human dignity, regardless of nationality or citizenship status. Still, the burden of responsibility for upholding human rights remains the task of nation-states. Whilst the international community are principal agents for promoting normative frameworks and applying pressure to fulfil promises regarding human rights, the nation states shoulder the primary responsibility in upholding such rights (Wilsher 2012). A key issue with Giorgio Agamben's assertions is that they appear to imply that refugees are without any recourse to clear sets of laws and legal remedies. Whilst the legal status often severely restricts access to remedies and justice, Agamben's (1998) assertions are perhaps in danger of too hastily disavowing the frameworks (even if somewhat ineffective) put in place through the existence of regional bodies like the European Community, and international treaties. Such measures pertain to a manner of governing the treatment of refugees and the setting of positive norms for treatment of non-citizens. As noted by Wilsher:

'Where they have suffered serious breaches of their civil rights, by being detained without lawful authority, [both refugee and immigration detainees] have not been denied access to justice to sue for damages or to challenge the legality of detention. In this sense they retain legal 
personality. Civil damages have also been awarded where detainees have suffered serious harm by reason of the conditions of detention' (2012, 302).

Nonetheless, such remedial justice - within the current climate of fortification/detention - remains elusive and difficult to access; bureaucratic barricades signify another element in the fortification of Europe. In a dangerous cycle, access to remedial justice is limited by the high number of (im)migrants/refugees ${ }^{1}$; the sheer volume of individuals seeking refuge in the UK has been crucial in defining this issues as a crisis. Considered in light of the institutional inability to provide adequate and timely remedial responses, as demonstrated by the lengthy existence of the Calais 'jungle' camps, the manner with which the refugee crisis is confronted does slide closer akin to the description put forward by Agamben.

Concurrently, online media narratives, such as those forged through the recurrence of social media artefacts and through online news (see above), have been instrumental in constructing the Calais 'jungle' as a liminal space of threat, inhabited by a threatening Other (Kelly and Hall 2015, The Daily Mail Online). This is reflective of a growing reactionary re-entrenchment to nationalism. In the UK and across Europe, antiimmigrant/anti-refugee populism has seen a strong resurgence; the UK Independence Party, the Jobbik Party in Hungary, Golden Dawn in Greece, Pegida (Patriotic Europeans Against the Islamization of the West) and Marine Le Pen's Front Nationale in France, for example, all rely on anti-immigration/anti-refugee rhetoric to fuel their growing popularity.

'Today's anti-immigrant populism has replaced direct barbarism with a barbarism that has a human face. It enacts a regression from the Christian ethic of 'love thy neighbour' back to the pagan privileging of the tribe over the barbarian Other. Even as it represents itself as a defence of Christian values, it is in fact the greatest threat to the Christian legacy. [...]The anti-immigrant defenders of Europe, not the notional crowds of immigrants waiting to invade it, are the true threat to Europe'. (Zizek 2014, 37)

Online media-scapes provide battlefields upon which ideological contradictions are being fought out; online artefacts reflect rhetoric used in the hope of winning the hearts and minds of the public, and garnering support. Particularly from 2004 to the present, European publics demand for immigration, refugee and asylum restrictions have been strong. Although state policymakers still face constraints in responding to such demands (Ford et al. 2014), there have been a succession of efforts across Europe to limit the movement of non-Europeans. The implementation of such restrictive measures must be considered within the context of the support located within anti-immigration and anti-refugee populism echoed throughout Europe.

According to Agamben (1998), political rhetoric such as that espoused in news (and social) media, coupled with humanitarian liberal claims indicates towards how (im)migrants/refugees function as 'inclusive exclusions' of bare life. Zoe is included through an exclusion from political life; in so doing, bare life (naked life) is produced

\footnotetext{
${ }^{1}$ The reasoning behind such semiotic delineations pertains to its own set of controversies.
} 
as something separate and different from political life. Agamben (1998) postulates that the camp represents a permanent state of exception in which law and chaos collide to create a zone of indistinction. Building upon Carl Schmitt's (1985) notions of sovereignty, Agamben claims those that inhabit the camp, homo sacer, are devoid of value. Violence against these sacred men will not be punished. However, whilst Schmitt (1985) defines sovereignty in its potential to declare the state of exception or not, Agamben (1999) proposes an alternative third possibility: the camp is no longer just an exclusive, secret space, compartmentalised and divided away from the social life of bios and the political community. Rather, Agamben (1999) claims, the state of exception can transgress the spatiotemporal boundaries of the camp within which it was once contained. Driven by an ethical impetus to expose the juridico-political mechanisms that make it possible to commit acts of violence that do not count as crime, Agamben (1999) draws attention to how decisions on the life of people are taken outside the normal framework of rule; these decisions, though, are not completely illegal nor without connection to the law.

Set within the current crisis, issues regarding nation-states suspending essential civil liberties for bodies inhabiting the many (im)migrant/refugee camps growing in and around Europe, such as Calais' jungle, which is now entering its thirteenth year in existence, can be seen as the physical emancipation of a normalised state of exception. An increasing fortification along the borders of Fortress Europe consolidate 'zone[s] of irreducible indistinction [...] the originary relation of law to life is not application but abandonment' (Agamben 1998, 29).

'He who has been banned is not, in fact, simply set outside the law and made indifferent to it but rather abandoned by it, that is, exposed and threatened on the threshold in which life and law, outside and inside, become indistinguishable' (Agamben 1998, 28).

Drawing up Roman law and the figure of homo sacer, or sacred man, these liminal spaces house those beyond the protection of the law (with no political rights) or even worthy to be sacrificed. The double exclusion, from both human and divine law, is simultaneously a double inclusion: homo sacer is excluded from both the sacred and the profane (Edkins 2003). This is not a figure only to inhabit political philosophy, it is a subject of recurrent materialisations throughout history (Dean 2004). The figure of homo sacer is the nexus between the materialization of the state of exception and its legitimising corollary, fearism of the Other, that un-obfuscates the limitations in the framework of both state-centric and liberal humanitarian notions (Papastergiadis 2006). This aspect of Agamben's (1998) work is significant for the considerations of the current crisis: the connection between one form of life is separated out and imagined as a figure necessary to fear. This Other becomes a threat to the life of 'society.' As demonstrated by factions of mass and social media capitalizing on cultures of fearism, the production of naked life is extended in a process that legitimises the fortressing of Europe.

A critical exponent of this culture of fearism has been the British (far-) right, and their use of online media. Particularly potent, replicating recurrent (post)colonial discourses, the internet has enabled these organisations to construct localised 'regimes of truth' (Said 1978; Foucault 1980) relating to national identity and negative identity formation through the promotion of a culture of fearism, against the foreign Other. As 
evidenced in the comments, likes and shares on these social network sites, the networked nature of social media has enabled sympathisers to find one another and build bonds between similarly minded individuals. Simultaneously, as demonstrated by the all too analogous sentiments and canons of content evident in broadsheet online medias, online mass media have also contributed to compounding a less extreme, yet equally pervasive culture of fear. In so doing, a culture of fear has been established, upon which the UK and European states have legitimised the Other to be disenfranchised of political and human rights.

\section{Conclusion: The Problematic of a Discursive Dichotomy}

The summer of 2015 has sent European politics into a panic; debates on the refugee crisis have been haunted by amnesia. As illustrated by the section on Fortressing Europe, this industry has been growing for some time: from the arrival of sub-Saharan Africans into Italy during the early 2000s, the Spanish canary Islands 'boat crisis' in 2006, as well as numerous other 'emergencies' - Europe has seen a succession of 'border crises' requiring border entrenchment and fortification. The succession of each crisis has given rise to ever increasing investment in border security. In turn, entrances to Europe have been displaced into ever more dangerous routes; the effect of which is the feeding of riskier routes and methods, provided by smuggler networks. Increasing efforts for Fortressing Europe result in a vicious cycle; the failure to control flows of (im)migrants, refugees and asylum seekers feeds a demand for ever greater fortification of European borders. As illustrated in the considerations above, this vicious cycle becomes intensified by the hegemonic narratives currently in circulation: many industries stand to proffer greatly whilst those attempting to cross these fortified borders face ever greater risks. A key issue this investigation seeks to bring to light is that of how social and mass online media have been incremental in streamlining the dialogue into a dichotomy foreclosing necessary further discussion and debate. Critically, the nature of how social media sites disseminate knowledge and (mis)information, and the effects of which, need to be considered; located and locked into the hyper emotively charged binary of anti-immigration vs. humanitarian narratives, pertinent issues worthy of consideration have been omitted from the debates dominating the public imagination. Agamben's work provides a useful framework through which the current crisis can be analysed. However, the complex networks and nexi linking European nation-states, media, military, border and detention complexes are also in need of scrutiny; these industries and tangled relationships are embroiled in vicious cycles and self-reinforcing economies legitimising the fortification of European border controls. Evidenced in the cultural artefacts considered, potent discursive dogmatics characterise this crisis's competing narratives; in so doing, Other important considerations about the grave costs of Fortressing Europe are not given due reverence.

\section{References}

Ahmed, S. (2004) The cultural politics of emotion, New York: Routledge

Agamben, G. \& Heller-Roazen, D. (1998) Homo sacer, Stanford, CA: Stanford University Press 
Agamben, G. (2000) Remnants of Auschwitz: the witness and the archive, New York: Zone Books

Agamben, G. (2005) State of exception, Chicago: University of Chicago Press

Agamben, G. (2009) What is an apparatus?: and other essays, Stanford, CA: Stanford University Press

Altheide, D. L. (2002) Creating fear: news and the construction of crisis, New York: Aldine de Gruyter

Andersson, R. (2014) Illegality, Inc. Clandestine Migration and the Business of Bordering Europe, Berkeley: University of California Press

Barthes, R., Miller, R., \& Howard, R. (1975) The pleasure of the text, New York: Hill and Wang

Blanchard, J. (2015) 'Officials Warn 20,000 ISIS jihadis 'have infiltrated Syrian refugee camps', Available at http://www.mirror.co.uk/news/uk-news/officialswarn-20000-isis-jihadis-6443516 Accessed 02/10/2015

Dathlan, M. (2015) 'Aylan Kurdi: David Cameron says he felt 'deeply moved' by images of dead Syrian boy but gives no details of plans to take in more refugees' Available at http://www.independent.co.uk/news/uk/politics/aylan-kurdi-davidcameron-says-he-felt-deeply-moved-by-images-of-dead-syrian-boy-but-gives-no10484641.html Accessed 10/10/2015

Dean, M. (2004) 'Four theses on the powers of life and death', Contretemps, 5, 16-29

Edkins, J. (2003) Trauma and the memory of politics, Cambridge:Cambridge University Press

Fagge, N. (2015) 'PASSPORT TO TERROR: MailOnline reporter buys Syrian papers being sold to ISIS fighters sneaking into Europe hidden among refugees' in The MailOnline Available at http://www.dailymail.co.uk/news/article3235320/PASSPORT-TERROR-MailOnline-reporter-buys-Syrian-papers-soldISIS-fighters-sneaking-Europe-hidden-refugees.html http://www.dailymail.co.uk/news/article-3235320/PASSPORT-TERRORMailOnline-reporter-buys-Syrian-papers-sold-ISIS-fighters-sneaking-Europehidden-refugees.html\%20 Accessed: 21/05/2016

Fahey, J. (2015) 'The Guardian's Decision to publish shocking photos of Aylan Kurdi Available at http://www.theguardian.com/commentisfree/2015/sep/07/guardiandecision-to-publish-shocking-photos-of-aylan-kurdi

Fassin, D. \& D'Halluin, E. (2005) 'The Truth from the Body: Medical Certificates as Ultimate Evidence for Asylum Seekers', American Anthropologist 107, 4, 597-608

Fisher, R. M. (2006) 'Invoking “Fear" Studies', Journal of Curriculum Theorizing, $22,4,39-71$.

Flynn, M. (2015) 'Bureaucratic Capitalism and The Immigration Detention Complex', Global Detention Project Working Paper No. 9, Available at http://www.globaldetentionproject.org/fileadmin/publications/Matt_Flynn_GDP_P aper_2015.pdf Accessed 18/10/2015 
Foucault, M. (1983) 'The subject and power: Afterword', in H. Dreyfus and P. Rabinow (eds.), Michel Foucault: Beyond structuralism and hermeneutics, Chicago: University of Chicago Press, pp. 208-227

Foucault, M. (2003) Society must be defended. Lectures at the Collège de France, 1975-1976 (eds. M. Bertani \& A. Fontana). New York: Picador

Foucault, M. (2007) Security, territory, population lectures at the Collège de France, 1977- 1978 (eds. M. Bertani \& A. Fontana), Basingstoke: Palgrave Macmillan.

Ford, R., Jennings, W., \& Somerville, W. (2015) 'Public opinion, responsiveness and constraint: Britain's three immigration policy regimes', Journal of Ethnic and Migration Studies Vol. 41, 9, 1391-1411.

Furedi, F. (2006) Culture of fear revisited risk-taking and the morality of low expectation, London: Continuum.

Guardian Online (2015) 'Migrant life in Calais' Jungle refugee camp - a photo essay' available at http://www.theguardian.com/media/nginteractive/2015/aug/10/migrant-life-in-calais-jungle-refugee-camp-a-photo-essay Accessed 09/09/2015

Hopkins, S. (2015) 'Rapper Ice Cube Mistaken As 'ISIS Convert Living in Birmingham' In Latest Meme Fooling Far-Right Supporters' Available at http://www.huffingtonpost.co.uk/2015/09/17/rapper-ice-cube-mistaken-for-isisfighter_n_8150916.html Accessed: 18/10/2015

Howarth, A. \& Ibrahim, Y. (2012) 'Threat and suffering: the liminal space of 'The Jungle', in Andrews, $\mathrm{H}$ and Roberts, L (eds) Liminal landscapes: travel, experience and space, Abingdon: Routledge, pp. 200-216

Ibrahim, Y. (2011) 'Constructing the Jungle, Distance Framing on the Daily Mail', International Journal of Media and Cultural Politics, 7, 3, 315-331

Journalism++ (2015) The Migrants Files, http://www.themigrantsfiles.com/ Accessed $21 / 18 / 2015$

Kelly, T. \& Hall, J. (2015) 'Syrian ISIS suspect 'is sleeping rough in Calais refugee camps in the hope of sneaking into the UK to wage terror' Available at http://www.dailymail.co.uk/news/article-3229134/Syrian-ISIS-suspect-sleepingrough-Calais-refugee-camps-hope-sneaking-UK-wage-terror.html Accessed 20/10/2015

Kember, S. \& Zylinska, J. (2012) Life after new media mediation as a vital process. Cambridge, MA: MIT Press

Koopmans, R. (2004) 'Movement and the media: Selection processes and evolutionary dynamics in the public sphere', Theory and Society, 33, (3), 367-391

Mamdani, M. (2010) Saviours and survivors: Darfur, politics and the war on terror, Lagos, Nigeria: Malthouse Press

Orgad, S. (2012) Media representation and the global imagination, Cambridge: Polity

Otto, D. (1996) 'Subalternity and International Law: The Problems of Global Community and the Incommensurability of Difference', Social And Legal Studies $53,337-364$ 
Papastergiadis, N. (2006) 'The invasion complex: The abject other and spaces of violence' Geografiska Annaler, 88 B, 4, 429-442

Robin, C. (2004) Fear: the history of a political idea, Oxford: Oxford University Press.

Said, E. W. (1979) Orientalism, New York: Vintage Books

Schmitt, C. (1985) Political theology: four chapters on the concept of sovereignty. Cambridge, MA: MIT Press

Schwartz-DuPre, R. \& Scott, R. (2012) 'Postcolonial Globalizaed Communication and Rapping in Kufiyya', Communication, Culture \& Critique 8, 3, 335-355

Seiter, E. (1989) Remote control: television, audiences, and cultural power, London: Routledge.

Shohat, E., \& Stam, R. (1994) Unthinking Eurocentrism: multiculturalism and the media, London: Routledge.

Sjoberg, G. (1999) 'Observations on Bureaucratic Capitalism' in J. L. Abu-Lughod (ed), Sociology for the Twenty-first Century: Continuities and Cutting Edges, Chicago: University of Chicago Press, pp. 23-33

Sontag, S. (1977) On photography, New York, Farrar, Straus and Giroux

Spivak, G. C. (1988) In other worlds: essays in cultural politics, New York: Routledge

Taylor, M.. Wintour, P. \& Elgot, J. (2015) 'Calais crisis: Cameron pledges to deport more people to end 'swarm' of migrants' Available at http://www.theguardian.com/uk-news/2015/jul/30/calais-migrants-make-furtherattempts-to-cross-channel-into-britain Accessed: 08/08/2015

Tyler, I. (2006) 'Welcome to Britain': The cultural politics of asylum', European Journal of Cultural Studies, 9, 2, 185-202

ViceNews (2015a) 'Everyone Will Make It One Day': Meeting the Calais Migrants Who Dream of England' in ViceNews Available at https://news.vice.com/article/everyone-will-make-it-one-day-meeting-the-calaismigrants-who-dream-of-england Accessed 21/09/2015

ViceNews (2015b) 'Calling Bullshit On the Anti-Refugee Memes Flooding the Internet' in ViceNews Available at http://www.vice.com/en_uk/read/kleinfeldrefugee-memes-debunking-846 Accessed 21/09/2015

Wilsher, D. (2012) Immigration detention: Law, history, politics, Cambridge: Cambridge University Press

Young, R. (1995) Colonial desire: Hybridity in theory, culture, and race, London: Routledge

Zembylas, M. (2009) Global economis of fear: Affect, politics and pedagogical implications, Critical Studies in Education, 50, 2, 1-13

Zembylas, M. (2010) 'Agamben's theory of biopower and immigrants/refugees/asylum seekers: Discourses of citizenship and the implications for curriculum theorizing', Journal of Curriculum Theorizing, 26, 2, $31-45$ 
Žižek, S. (2008) Violence: Six sideways reflections, New York: Picador

Zizek, S. (2014) 'Barbarism with a Human Face', London Review of books Vol. 36 No. 98 May 2014, 36-37

\section{Images}

Figure 1: Image taken from British First Facebook page: https://www.facebook.com/OfficialBritainFirst/photos/pb.300455573433044.2207520000.1447576622./889450511200211/?type=3\&theater [Accessed 20/10/2015]

Figure 2: Image scraped from publically available Twitter account through a search of \#AylanKurdis [Accessed: 29/9/2015]

Figure 3: Image taken from Britain Furst Facebook Page: https://www.facebook.com/BritiainFurst/photos/pb.722772297798171.$\underline{2207520000.1447577221 . / 985594068182658 / \text { ?type }=3 \& \text { theater [Accessed }}$ 21/9/2015]

Figure 4: Image scraped from publically available social media account accessed through Google reverse image search of https://pbs.twimg.com/media/COhH3jxVEAAYNW-.jpg [Access 30/92015]

Alexander Harrison is a doctoral Candidate at Queen Mary University of London. Having completed an undergraduate degree in International Relations (Goldsmiths) and a Masters in International and Comparative law (SOAS), specializing in Human Rights Law, he is currently undertaking a doctoral degree exploring how new media(tions) affect riots and contentious politics (Queen Mary University of London).

Email: a.c.harrison@qmul.ac.uk 